Review

\title{
Environmental and Social Risks to Biodiversity and Ecosystem Health-A Bottom-Up, Resource-Focused Assessment Framework
}

\author{
Roger A. Pielke Sr. ${ }^{1, *}$, Jimmy Adegoke ${ }^{2}$, Faisal Hossain ${ }^{3}$ and Dev Niyogi 4 \\ 1 Cooperative Institute for Research in Environmental Sciences, University of Colorado, \\ Boulder, CO 80309, USA \\ 2 College of Arts and Sciences, University of Missouri-Kansas City, Kansas City, MO 64110, USA; \\ adegokej@umkc.edu \\ 3 Civil and Environmental Engineering, University of Washington, Seattle, WA 98195, USA; \\ fhossain@u.washington.edu \\ 4 Jackson School of Geosciences, University of Texas at Austin, Austin, TX 78712, USA; happy1@utexas.edu \\ * Correspondence: pielkesr@cires.colorado.edu
}

check for

updates

Citation: Pielke, R.A., Sr.; Adegoke,

J.; Hossain, F.; Niyogi, D.

Environmental and Social Risks to

Biodiversity and Ecosystem

Health-A Bottom-Up,

Resource-Focused Assessment

Framework. Earth 2021, 2, 440-456.

https://doi.org/10.3390/earth2030026

Academic Editor:

Samuel Asumadu-Sarkodie

Received: 5 June 2021

Accepted: 5 July 2021

Published: 12 July 2021

Publisher's Note: MDPI stays neutral with regard to jurisdictional claims in published maps and institutional affiliations.

Copyright: (c) 2021 by the authors. Licensee MDPI, Basel, Switzerland. This article is an open access article distributed under the terms and conditions of the Creative Commons Attribution (CC BY) license (https:/ / creativecommons.org/licenses/by/ $4.0 /)$.

\begin{abstract}
Risks from human intervention in the climate system are raising concerns with respect to individual species and ecosystem health and resiliency. A dominant approach uses global climate models to predict changes in climate in the coming decades and then to downscale this information to assess impacts to plant communities, animal habitats, agricultural and urban ecosystems, and other parts of the Earth's life system. To achieve robust assessments of the threats to these systems in this top-down, outcome vulnerability approach, however, requires skillful prediction, and representation of changes in regional and local climate processes, which has not yet been satisfactorily achieved. Moreover, threats to biodiversity and ecosystem function, such as from invasive species, are in general, not adequately included in the assessments. We discuss a complementary assessment framework that builds on a bottom-up vulnerability concept that requires the determination of the major human and natural forcings on the environment including extreme events, and the interactions between these forcings. After these forcings and interactions are identified, then the relative risks of each issue can be compared with other risks or forcings in order to adopt optimal mitigation/adaptation strategies. This framework is a more inclusive way of assessing risks, including climate variability and longer-term natural and anthropogenic-driven change, than the outcome vulnerability approach which is mainly based on multi-decadal global and regional climate model predictions. We therefore conclude that the top-down approach alone is outmoded as it is inadequate for robustly assessing risks to biodiversity and ecosystem function. In contrast the bottom-up, integrative approach is feasible and much more in line with the needs of the assessment and conservation community. A key message of our paper is to emphasize the need to consider coupled feedbacks since the Earth is a dynamically interactive system. This should be done not just in the model structure, but also in its application and subsequent analyses. We recognize that the community is moving toward that goal and we urge an accelerated pace.
\end{abstract}

Keywords: climate assessments; global climate modeling; environmental vulnerability; sustainability; risk

\section{Introduction}

The vulnerability of species and ecosystems to weather and climate continues to be an important concern. Extremes of weather, for example, such as prolonged drought, destructive hurricane landfalls, heat and cold waves can cause havoc and even alter the biodiversity and function of entire ecosystems [1-3]. Indeed, movement of plant and animal species has always been dynamic as the climate has changed over time. The change from the Pleistocene to the Holocene is a recent example of how such profound changes can occur (e.g., [4]). In the contemporary climate, human activity has become involved as a major forcing of these changes. Examples of these forcings include the emission of $\mathrm{CO}_{2}$ 
and other greenhouse gases and aerosols such as black carbon and nitrogen oxides into the atmosphere from industrial, vehicular and land management sources, and the conversion of land to agriculture or other human uses $[5,6]$.

However, the focus on developing strategies for biodiversity conservation in response to these forcings, which are in addition to forcings that have always occurred naturally (e.g., see $[7,8])$, has emphasized $\mathrm{CO}_{2}$ and other human greenhouse emissions-based impacts. There are risks, however, in constraining what the actual threats to species and ecosystems are. These threats are particularly important with mixed and managed ecosystems such as in agriculture, urban areas, and many forest landscapes.

Hulme [9] outlines different narratives and framings of climate issues. In particular, building off Hulme $[9,10]$, we note two framings that have emerged and are used in the community (see Figure 1). These are:

(1) 1st Framing-human greenhouse gas (GHG) emissions are the dominant human climate change forcings;

(2) 2nd Framing-multiple anthropogenic forcings on climate, including GHG emissions, but also land-use changes, and aerosol pollution, along with natural climate forcings are all of first-order importance in affecting climate.

Framing 1

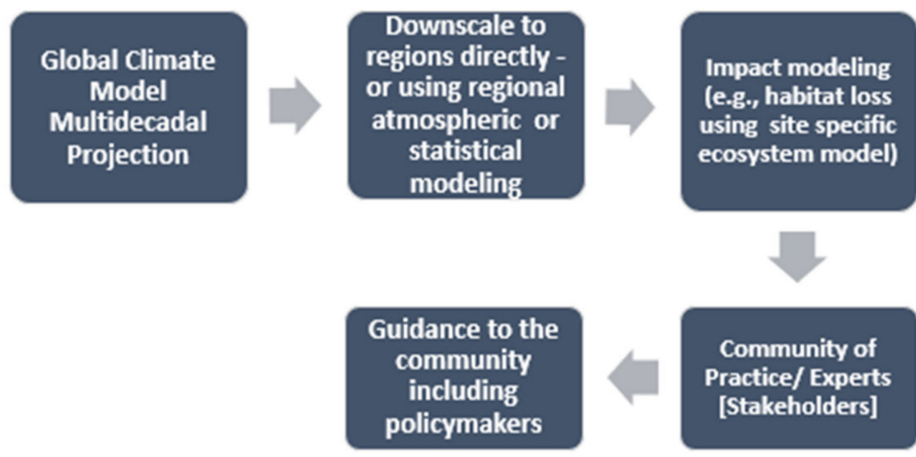

Framing 2

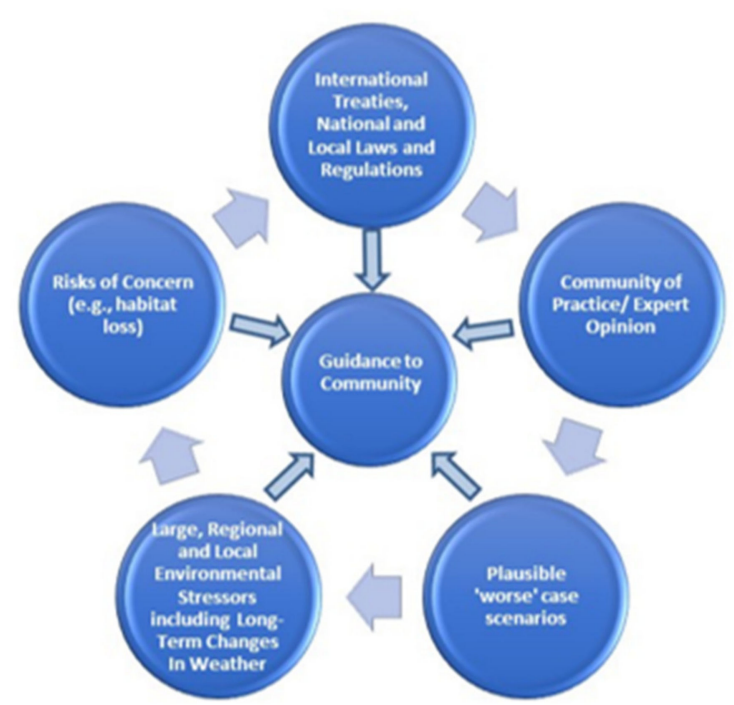

Figure 1. Schematic of framing of climate issue based on Hulme $[9,10]$.

The Hulme [9] commentary highlights that "these two different provocations-two different framings of climate change-open up the possibility of very different forms of public and policy 
engagement with the issue. They shape the response". Polasky et al. [11] also urge a rethinking of how to approach human intervention into the environment including the climate.

Large-scale climate-based assessments typically built on the 1st framing (in which human greenhouse gas emissions are the most significant threat) is one approach. In contrast, the 2nd framing considered at the local and regional scale, climatic changes due to land use/land management, aerosol forcing, and other human interventions, however, can be comparable, stronger than, or counter the effect from greenhouse gas emissions based on forcing alone. An example of significant land-use transformation is due to urbanization. While the urban heat island (UHI) is a small fraction of global mean temperatures as reviewed, for instance, in [12]; at the regional scale UHI impacts on temperature can be an order of magnitude higher than the large-scale climate change effect from added GHGs for the corresponding period (e.g., $[13,14])$.

Other land-use changes, in addition to the urban effect, can similarly have effects on regional climate that are at least as large as from added GHGs (e.g., [8,15-25]). Niyogi [22], for example, reported on increasing heavy rains in India with resulting alterations in hydroclimate due to changes in land use and land cover.

Our paper, therefore, recommends broadening the assessment of environmental vulnerability beyond risks from the addition of greenhouse gases to the atmosphere. When the latter is presumed to be the dominant threat, yet other risks may be as large or larger, policy responses will be misdirected and effective approaches to environmental sustainability missed.

\section{Terminology}

Before discussing an improved framing, we need to make sure our terminology is precise. First, weather is generally understood to be short term variations in atmospheric quantities such as temperature, humidity, precipitation, cloud cover, radiation, and winds. Time periods extend from today out to a couple of weeks, and at most, a season. Weather models have the advantage that thousands of observations are inserted into the models at frequent intervals in order to constrain any drift of the models from reality [26]. The model forecast skill can also be straightforwardly and every day validated against what actually occurred.

Climate has two definitions. The first definition is that the climate is the long-term weather statistics of specific geographical locations. The issue though is what is meant by "long-term" (i.e., what time interval is the forecast for)? Weather prediction itself involves statistics such as the U.S. National Weather Service forecasts of daily precipitation totals, daily maximum and minimum temperatures, for instance. The U.S. Climate Prediction Center provides seasonal forecasts as probabilities of mean temperature (or precipitation) falling into the most likely of three classes based off 30-year observed climatology (such as 1981-2010)-either above-near-or below normal (median). While for infrastructure design a 100-year frequency is used for planning purposes- even if such a long period of record is not available [27].

In terms of threats to species and ecosystems, a broader definition of climate is often needed. The inclusive definition of climate is that it is the coupled ocean-atmosphereland-cryosphere-human system. It involves physical-biological-geochemical interactions including interfacial fluxes across the different mediums. With this inclusive framing "climate" means the climate system. This was the definition adopted in [28] and illustrated schematically in Figure 2. 


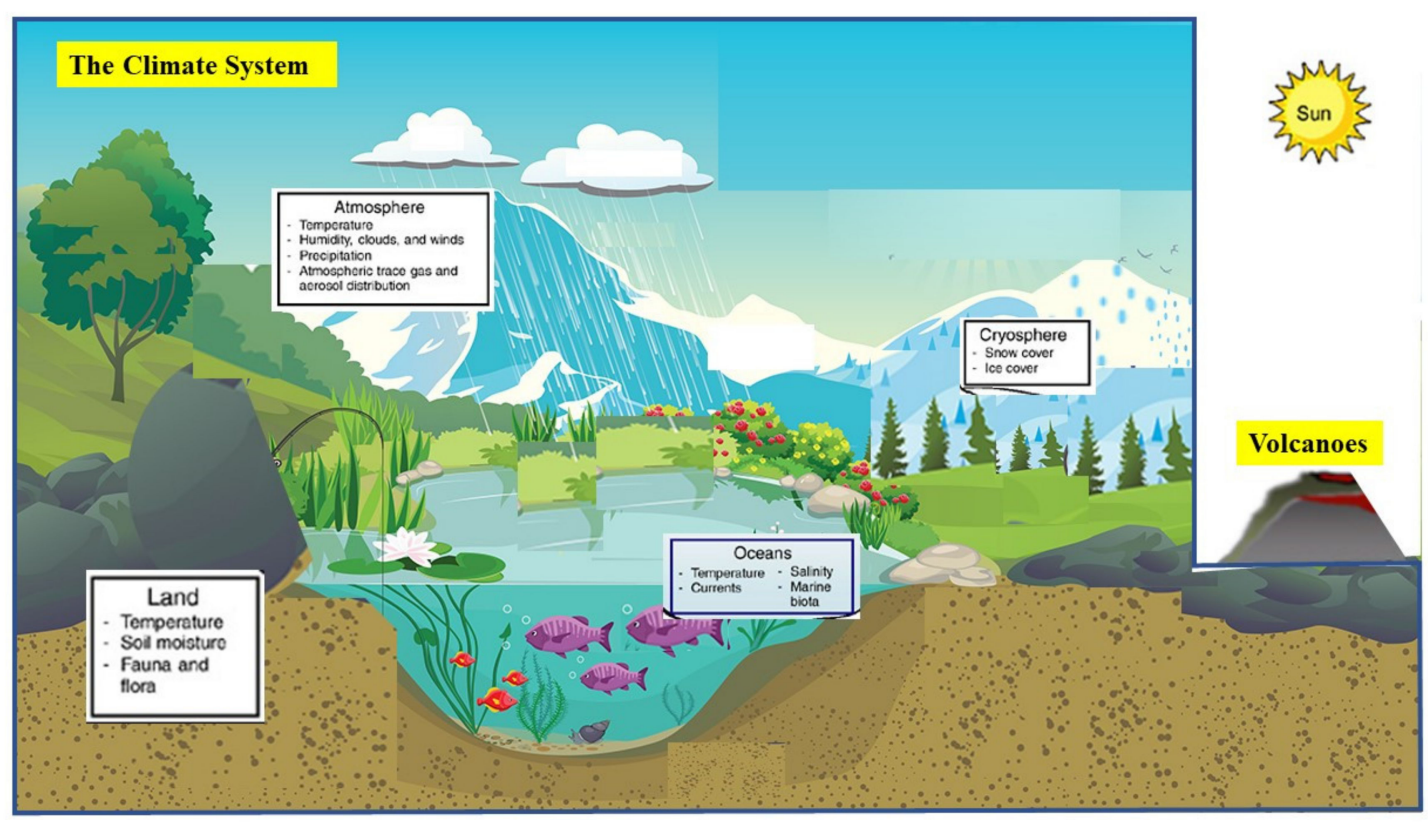

Figure 2. The climate system, consisting of the atmosphere, oceans, land, and cryosphere. Important state variables for each sphere of the climate system are listed in the boxes. For the purposes of this report, the Sun, volcanic emissions, and human-caused emissions of greenhouse gases and changes to the land surface are considered external to the climate system (adapted from [8] by Olusola Festus, University of Missouri Kansas City).

This schematic also shows why the second framing from Hulme [9] in which there is a diverse range of first-order human climate forcings is a better way to characterize the range of threats. Indeed, defining climate in this manner is just recognizing that the Earth's environment is a human-influenced ecological system. On Earth, there is no "physical climate" by itself. The terms "climate" and "ecology" are the same thing except viewed and framed from the physical and the biological communities, respectively.

Rial et al. [29] and Sveinsson et al. [30] present examples demonstrating that the Earth's climate system is highly nonlinear, that inputs and outputs are not proportional, that change is often episodic and abrupt, rather than slow and gradual, and that multiple equilibria are the norm. This highlights the need to add value beyond using global models scenarios to frame social and environmental risks to ecosystem health. Peters et al. [31], for instance, shows that the ecological system has spatial nonlinearities which result in critical environmental thresholds. Thus what may be an appropriate mitigation response for one spatial scale of a disturbance may not be transferable to a different spatial scale. Moreover, the global model multidecadal regional predictions of changes in climate statistics are not showing needed skill (e.g., [32,33]). Moreover, despite the limited skill reported by the IPCC [33] in Chapter 11, results are presented for multidecadal time periods in Chapter 12 [33] and Annex I [33] and are used by the impact community as if they have skill. This is misleading as the model predictions have not demonstrated the needed skill. Even on the global scale, skill in predicting changes in the global averages shows limited skill $[34,35]$. The large-scale outcomes are also sensitive to issues raised with respect to the forcings from emissions [36-38]. As shown in [36] for example, IPCC baseline scenarios have over-projected $\mathrm{CO}_{2}$ emissions.

\section{Human Intervention in the Climate System}

Examples of human intervention into the climate system include human emissions of $\mathrm{CO}_{2}$, other greenhouse gases, and aerosols, deposition of these aerosols on land and ocean, land cover change and land management practices, discharge of effluent into rivers, lakes and oceans; introduction of invasive species; and agricultural and engineering management [5]. These human forcings not only affect the radiative fluxes in the climate system, 
but also have biogeochemical effects, such as from nitrogen deposition, the biological effect of added $\mathrm{CO}_{2}$, and hydroclimatic changes such as inundation and altered seasonal hydrology through dams or irrigation, and regional policies such as investment in renewable energy etc. Most of the risks faced by species and ecosystems are regional and local, and only weakly connected to a global average of any metric including a global annual mean surface temperature anomaly. Figure 3 illustrates the process flow that is outlined in the climate system shown in Figure 2.

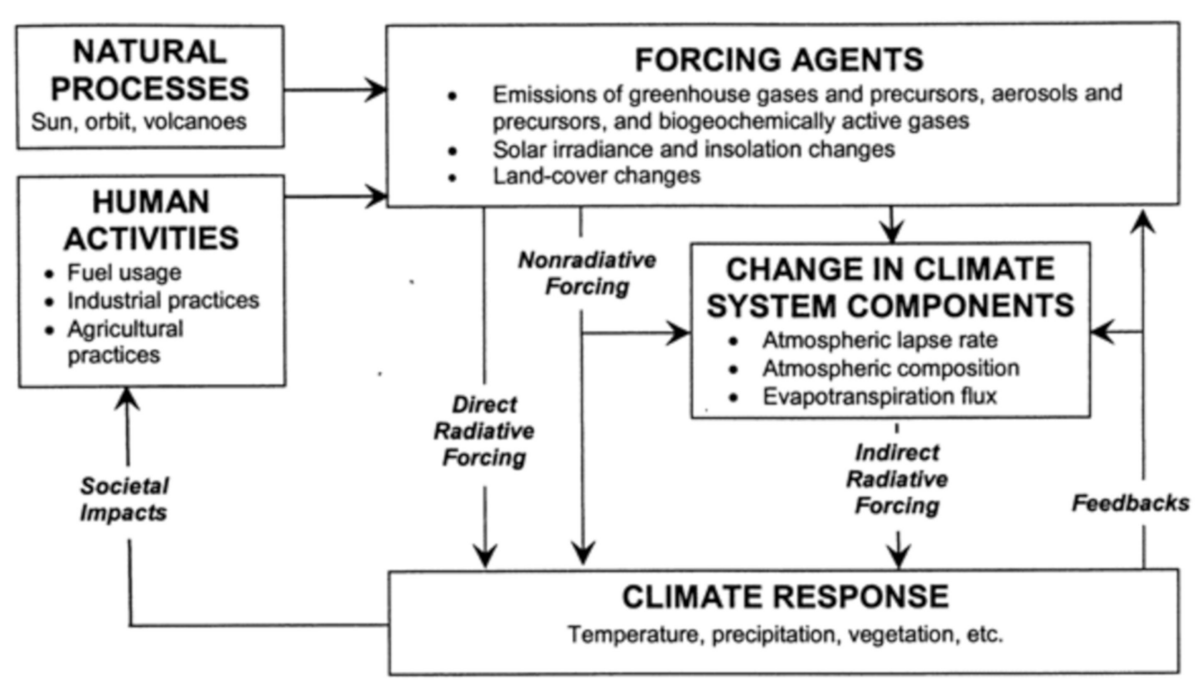

Figure 3. Conceptual framework of climate forcing, response, and feedbacks under present-day climate conditions. Examples of human activities, forcing agents, climate system components, and variables that can be involved in climate response are provided in the lists in each box from [28].

\section{Top-Down Assessment of Vulnerabilities}

Many assessments and research studies typically start from a GCM-based and downscale to regional and local impacts (e.g., [39-42]). The broad framework builds on the projection of climate decades into the future (in which the assessments refer to climate change or projected climate). This is the outcome vulnerability approach illustrated on the left panel of Figure 4.

For the top-down approach, Figure 5 illustrates the generally used starting point using global climate models to assess and predict human-caused climate change. Radiative forcing is the driving effect used to project the resultant response of the climate. However, there are large uncertainties even in this global-averaged forcing [36]. Regional variations in this radiative forcing and their effects are not properly considered. This top-down view is illustrated in how [45] is structured. The three-volume report, which is summarized in [45], starts with the Working Group 1 report of the IPCC which focuses on the global scale with the title "Climate Change 2013: The Physical Science Basis". The following two volumes build substantively based on the conclusions of the first volume and have the titles AR5 "Climate Change 2014: Impacts, Adaptation, and Vulnerability" and "AR5 Climate Change 2014: Mitigation and Climate Change". They extensively use information from the first report to assess vulnerabilities (those two IPCC follow-on reports focus on the outcome vulnerability approach with only a few exceptions). Also, the 2013 IPCC report [33] is titled the "Physical Science Basis" of climate change. However, as discussed in this paper, it is necessary to look beyond the physical component of the climate system as part of the Earth system. Figure 5 also illustrates how global forcing is translated to regional and local environmental impacts (represented by "other impacts" in the figure). Starting with the global atmospheric or global atmospheric-ocean models, this is a top-down perspective where the large-scale forcing dictates the environmental impact. Often, regional dynamic 
or statistic models [46] are used to downscale the global model information to scales useful to the environmental impacts community (e.g., [47]).

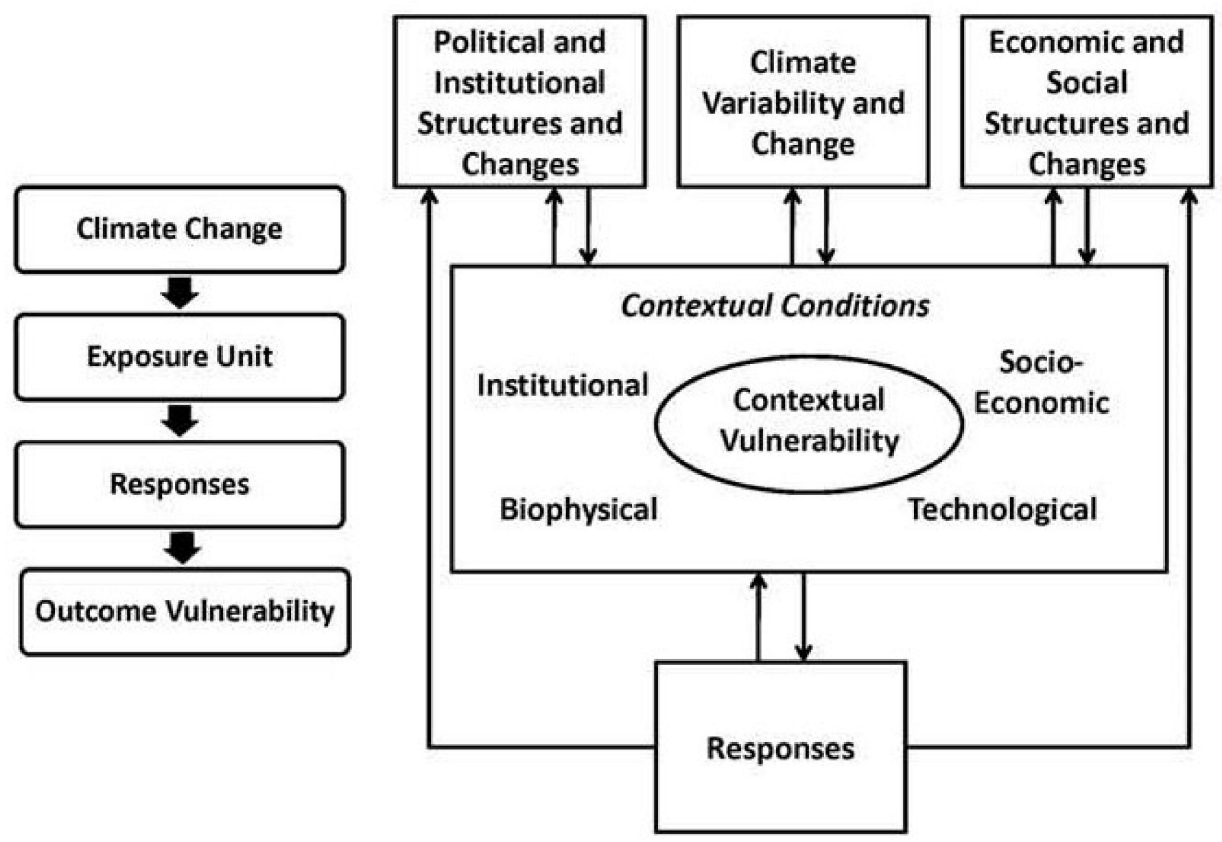

Figure 4. Framework depicting two interpretations of vulnerability to climate change: (left) outcome vulnerability and (right) contextual vulnerability. Adapted by D. Staley from the works of $[43,44]$.

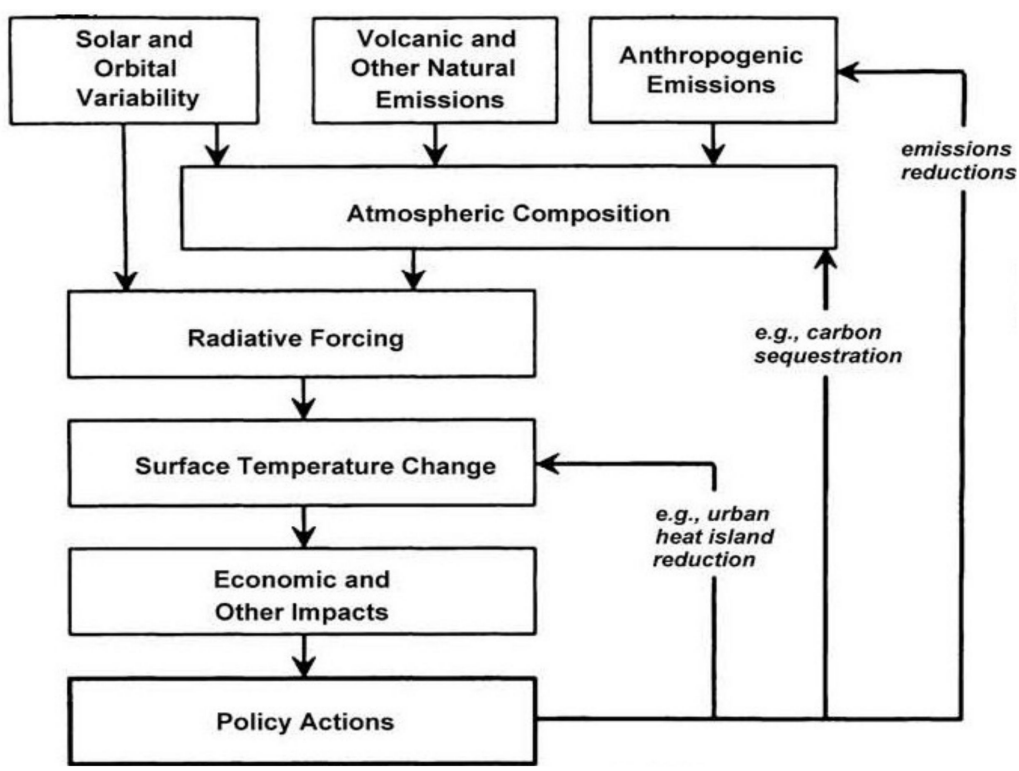

Figure 5. Conceptual framework showing how radiative forcing fits into the climate policy framework from [28].

This is the procedure used, for example, by the U.S. National Assessment where regional impacts were defined for much of the 21st century based on this downscaling [48]. This approach is useful as "what if" sensitivity model studies. Examples include assessing the broad framework and relative importance of different forcings and comparing the results across different assessments (e.g., [49,50]).

A necessary condition for using the top-down approach is that the global climate models provide skillful forecasts of changes in climate statistics on the regional and local scales for the time period of interest. It is important to emphasize that it is the changes that 
must be skillfully predicted. Current and recent historical climate statistics and changes over time in these statistics from the climate models in hindcast runs should be compared with local observed climate data records and reanalyses products such as ERA-5 and JMA55. The concept and value of reanalyses are discussed in [51]. A necessary condition to use the climate model as robust predictions for future decades is a demonstrated ability to predict, in hindcast runs, the observed longer-term changes in the climate statistics in the reanalyses. While not a complete test of skill (as input data such as vegetation distribution are prescribed and parameterizations in the models are tuned to today's climate), they are an essential test.

The Earth's ecosystems exist in the oceans and on land. While land covers less than $30 \%$ of the Earth's surface, its effect on climate through biophysical and biogeochemical processes, and thus on ecosystem function, can be disproportionally large [52]. Thunderstorms, for example, predominantly occur over land (by a 10:1 ratio; e.g., see Figure 10 in [15]). This preference for deep convection over land is because energy for deep cumulus clouds is typically larger over land as diurnal solar heating typically creates larger surface heat fluxes during daylight which fuels the intensity of these storms as discussed in Appendix A of [51]). It has also been shown $[53,54]$ that much of the energy transported upwards in the tropics and then poleward, occurs because of these deep-convective thunderstorms which are the starting point for the major, global-scale, circulation cells such as the Hadley and Walker cells. These studies demonstrated that 1500-5000 thunderstorms, which they refer to as "hot towers", are the conduit to transport heat, moisture, and wind energy to higher latitudes. Since these thunderstorms occur mostly over land, any change in their spatial patterns due to land use/land-cover change, including vegetation or anthropogenic aerosols would be expected to have global climate consequences (e.g., [55]). Indeed, this human-caused change in thunderstorm patterns caused by the diverse regional climate forcings identified in this paper may have a greater effect on the climate system and ecosystem function beyond the radiative effect of doubled $\mathrm{CO}_{2}[56,57]$.

Thus the current top-down approach adopted by use of GCMs to provide predictions of changes in environmental (climate) conditions in the coming decades has to overcome their lack of robust regional prediction skill as well as to include a more accurate representation of regional and local processes including all important human climate forcings. The challenge, therefore, is to develop an alternative or complementary approach to assess risk to environmental resources, including species health and ecosystem function.

The ecological community has been recognizing this shortcoming. For instance, Lawler et al. [58] writes "uncertainty in projected climate change impacts is one of the greatest challenges facing managers attempting to address global change". Kittel et al. [59] write "[h]igh uncertainty in the future of regional climates and ecosystems presents a challenge to the conservation of biodiversity and landscapes".

\section{Bottom-Up Assessment of Vulnerabilities}

A new vulnerability bottom-up paradigm was proposed in [60] to identify critical vulnerabilities in key resources and then seek optimal adaptation and mitigation strategies. (Figure 4 right side in-the contextual vulnerability perspective). The vulnerability paradigm, as applied to the Earth system, is a more inclusive approach than only focusing on the global model predictions for ecosystem impact studies. Kittel [61] concludes that "biodiversity is vulnerable to changing climate conditions across its breadth and depth-that is to say, altering composition, structure, and function of species genetics and populations and of communities, ecosystems, and landscapes." As he writes this vulnerability is "highly interwoven across these levels and across temporal and spatial scales, as well as being context dependent".

There are examples of the ecological community recognizing need for a bottom-up view when considering land-use change impacts [62] and using the Driver-Pressure-StateImpact-Response (DIPSR) method and related frameworks (e.g., [63,64]) to complement the multi-decadal climate predictions. 
The environmental and human-caused threats extend well beyond long-term changes in weather statistics including extremes. The framework for the contextual vulnerability assessment approach provides a local and regional perspective, in contrast to starting with the global climate models which is a top-down approach from a global perspective.

The vulnerability focus is on the resource of interest; in this paper it is ecosystem function including species diversity and health. The challenge is to use resource specific models and observations to determine thresholds at which negative effects occur associated with this resource. Changes in the environment from added $\mathrm{CO}_{2}$ and other greenhouse gases, represent a subset of the threat. Moreover, the climate system itself can be significantly altered by changes such as due to urbanization or agricultural practices and of other land management. There are multiple, nonlinear interactions between the forcings as shown by the dashed lines in Figure 6.

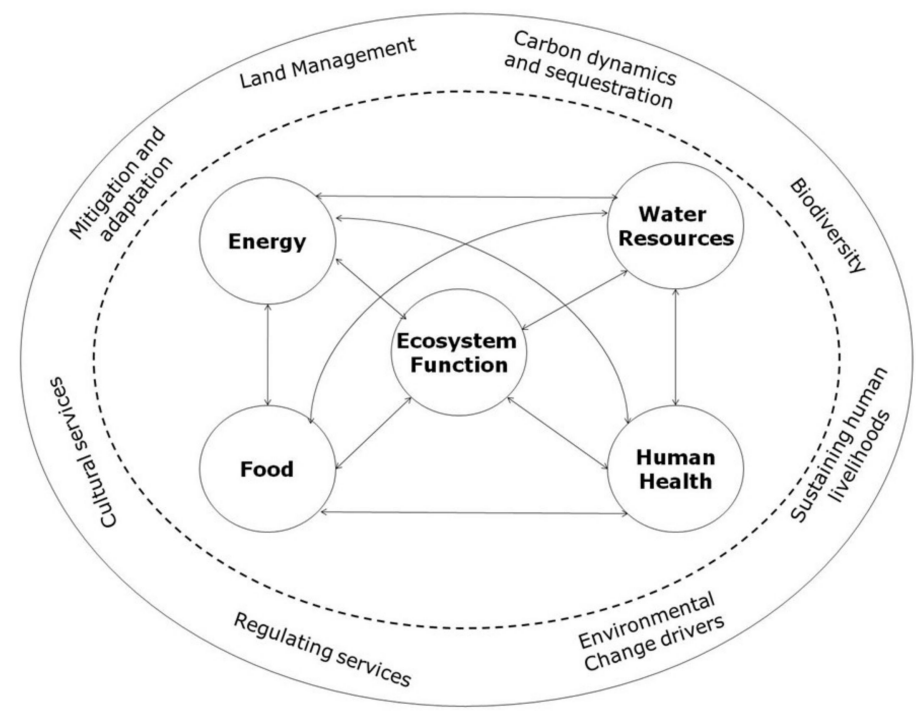

Figure 6. Schematic of the relation of ecosystem contextual vulnerability to the spectrum of the environmental forcings and feedbacks. The arrows denote nonlinear interactions between and within natural and human forcings from [65].

One of the approaches to assess vulnerability is through stakeholder participation and by querying the impact community about their experience of effects due to current weather and longer term (climate) trends and variability, and their thresholds for deleterious effects. Also what adaptation and/or mitigation strategies are (or could be) performed to reduce this vulnerability?

These questions for the stakeholders can be framed more explicitly as follows:

(1) Why is this resource (e.g., ground water) important? How is it used (e.g., drinking, irrigation, industry)? To what stakeholders (e.g., agrobusinesses, ecological restoration) is it valuable?

(2) What are the key environmental (e.g., rainfall change) and social variables (e.g., ground water pumping) that influence this resource?

(3) What is the sensitivity of this resource to changes in each key variable at different time and space scales? In terms of time scales, this includes, but is not limited to, the sensitivity of the resource to environmental variations and changes on short (e.g., days), medium (e.g., seasons), and long (e.g., multidecadal) timescales. Space scales include habitats, landscapes, water basins and migratory ranges.

(4) What changes (thresholds) in these key variables would have to occur (and at what scale) to result in a negative (or positive) response to this resource? What is the available natural (e.g., riparian zoning) and management (e.g., governance) tools for resistance and resilience to these changes? 
(5) What are the best estimates of the probabilities for these changes to occur (at different time scales; e.g., next 10 years; near 30 years etc.)? What tools are available to quantify the effect of these changes, and over what time frame? Can these estimates be skillfully predicted?

(6) What actions (adaptation/mitigation) can be undertaken in order to minimize or overcome the negative consequences of these changes (or to optimize a positive response)?

(7) What are specific recommendations for policymakers and other stakeholders in light of these assessments?

Note that the above seven questions provide an example of the prescriptive pathway for adopting the vulnerability framework. Kling et al. [66] and Ordonez [67] have taken steps in this direction by highlighting the need to analyze the interaction between vulnerability paradigms when defining suitable conservation, management, and adaptation strategies. Pielke Jr. [68] recommends a framing of the policy response as the following: If a science issue has value consensus and low uncertainty and if it is connected to policy, then the scientist should serve as "science arbitrator". If the issue is not connected to policy, the scientist works a "pure scientist". However, if the issue does not have value consensus and/or has significant uncertainty, then the scientist can serve as an "issue advocate" if they argue for a particular reduction in scope of the issue or as an "honest broker" if the scientist presents to the policymakers the suite of uncertainties.

Moss et al. [69] summarize the approaches that have been used to create scenarios for climate change research and assessment for the IPCC reports. They discuss a sequential approach (their Figure 3; reproduced here as Figure 7) where socio-economic scenarios are the starting point and then these are fed into emission scenarios, then radiative scenarios and climate model scenarios and finally impact, adaptation, vulnerably studies (the outcome vulnerability approach). They also present (their Figure 4; reproduced here as Figure 8) what they refer to as the parallel process which begins with identification of radiative forcing characteristics that support modeling of a wide range of possible future climates. They then split into two pathways-one on socio-economic emission scenarios, some of which are consistent with the radiative forcing pathways they selected and others are independent of those results, and a second pathway with climate scenarios. Then they merge the climate model and socio-economic scenario pathways. Finally, they assess impact, and adaption and vulnerability studies. Despite these somewhat convoluted pathways, the approach still invokes the outcome vulnerability approach, with a narrow view of what the future could be.

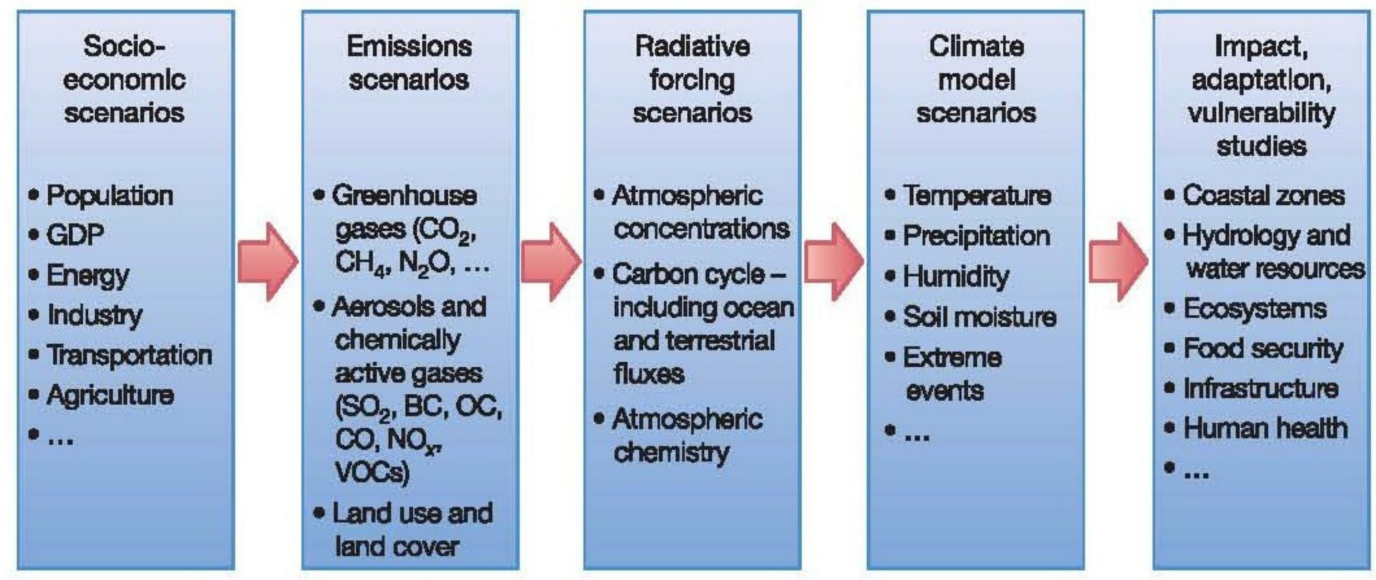

Figure 7. This figure depicts a linear chain of causes and consequences of anthropogenic climate change. Scenarios are developed on the basis of this sequence and handed from one research community to the next. From [69] with an edited caption. 


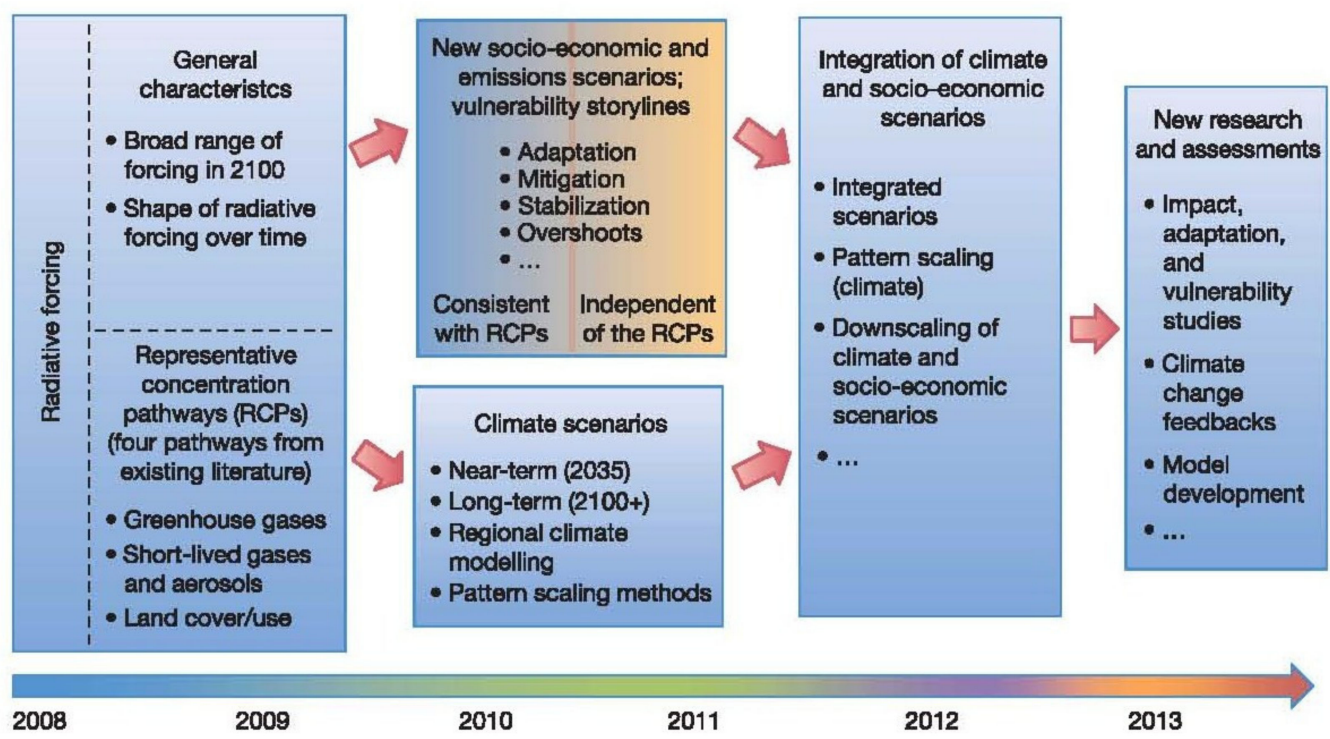

Figure 8. Scenarios began with the identification of radiative forcing characteristics that support modelling of a wide range of possible future climates. Representative concentration pathways (RCPs) are selected from the published literature to provide needed inputs of emissions, concentrations, and land use/cover for climate models. In parallel with development of climate scenarios based on the RCPs, new socio-economic scenarios (some consistent with the radiative forcing characteristics used to identify the RCPs and some developed to explore completely different futures and issues) are developed to explore important socio-economic uncertainties affecting both adaptation and mitigation. Using a variety of tools and methods, such as pattern scaling, the new socio-economic scenarios are integrated with the new climate scenarios. This framing is used to provide insights into the costs, benefits, and risks of different climate futures, policies, and socio-economic development pathways. From [69] with an edited caption.

As Kittel [61] writes "inherent limitations in predicting outcomes of vulnerability's complex dynamics, coupled with uncertainties in future forcings, make it difficult at best to anticipate specific consequences". This paper presents a framework to handle uncertainty which includes qualitative scenarios of climatic and ecological change based on expected as well as less probable but plausible futures not tied to specific model projections, as one approach. The recommendations are summarized as:

(1) Expert synthesis of established knowledge, providing an opportunity to gain insights into the resistance and resilience of species and systems to a changing climate and, based on this, to devise strategies to reduce or cope with this risk.

(2) Scenario ("what if") planning gives us the means to not rely on climate and ecological model projections for systems whose complexities are inherently difficult to simulate; rather, scenario planning gives us a framework with which to envision consequences to biodiversity across a broad spectrum of plausible futures (including conceivable 'surprises').

(3) A "no-regrets" goal (consider spectrum of plausible risks) guides us to implement climate-adaptive strategies which benefit current conservation needs by also decreasing species and system vulnerabilities to the suite of other threats.

(4) Adaptive management (permit short-term adjustments as knowledge is gained) protocols give conservation programs the flexibility to adjust strategies to changing conditions and advances in our understanding.

Included in such a framing, of course, has to be the recognition that climate change is not an external forcing to the ecosystems of the world, but is an integral and intimate component involved in the dynamics of the highly nonlinear interconnected climate system $[28,70]$.

Marland [18], for instance, writes "climate mitigation policies do not generally incorporate the effects of ... changes in the land surface on the surface albedo, the fluxes of sensible and latent heat to the atmosphere, and the distribution of energy within the climate system. Changes in these 
components of the surface energy budget can affect the local, regional, and global climate. Given the goal of mitigating climate change, it is important to consider all of the effects of changes in terrestrial vegetation and to work toward a better understanding of the full climate system".

Thus the climate system and the Earth's ecosystem are, as previously noted, just two terms for the same thing. The Gaia concept was introduced by Lovelock and Margulis [71] to recognize this multiple interfacial connections between the biological, chemical, and physical components of the Earth. The contextual vulnerability approach permits the proper assessment of risks associated with this intimately coupled system.

\section{Examples of Application of the Bottom-Up Paradigm to Assess Vulnerability}

As an example, one of the authors (Pielke Sr.) challenged Charlie Vorosmarty [72] at a UNESCO meeting in Paris to assess whether population growth or the changes in climate predicted by the global models was the greater threat to potable water supplies. This consequently led to the paper Vorosmarty et al. [73] which stated, "We conclude that impending global-scale changes in population and economic development over the next 25 years will dictate the future relation between water supply and demand to a much greater degree than will changes in mean climate".

This examination of risk from the point of perspective of the resource (e.g., potable water), is a much more robust approach than seeking to assess threats starting from a global model perspective and then downscaling to regions and localities. As reported in Pielke et al. [15] we tested this approach for a specific community located in Larimer County, Colorado, where agriculture is a major local industry. Selected examples of this community were polled in early summer 2004 using a five-category scale with respect to their impact of a long-term precipitation drought in this area. The four groups that provided input were Anheuser-Busch, Fort Collins Municipal Water, Grant Family Farms, and Dryland Farming. Despite very similar long-term temperature and precipitation in this area, the impacts on the different sectors were quite diverse. The major problem identified was the uneven distribution of the available water which, by Colorado water law, is based on water rights determined by seniority. This example illustrates that access to water involves more than climate, and also involves laws and regulations that are complex in their own right [74]. With a bottom-up perspective, the distribution of agricultural and other impacts across a community can be explicitly considered, and objectively confirmed, as a more inclusive and accurate assessment of the local impacts. Then the fundamental question becomes about seeking ways to mitigate and/or adapt to the threats to these local resources. This can then be a more societally and environmentally beneficial approach than only relying on the results of downscale to the local region from a global climate model.

Another example is the relative risks from changes in regional and local climate as contrasted with invasive species [75-77]. Examples of destructive invasive species include the chestnut blight, Cogongrass (Imperata cylindrica), and Dutch elm disease to name just a few. These invasives not only affect individual species but can alter entire ecosystems, such as the chestnut blight that decimated American chestnut (Castanea dentata), a dominant deciduous tree in the northeast USA prior to the 20th century. While changes to local climate are certainly a threat and have caused extinctions (e.g., [78]), so far such a widespread loss of a species by changes in global average surface temperature increase and its consequences to the local climate alone has not been shown. On the local scale, land-use change and invasive species are the larger threat at present [76].

Fires are another factor that can certainly be exacerbated by weather extremes and long- term changes in weather patterns, but forest management including fire suppression over the years has played a major role; for instance, in the devastating fires in the western USA in recent decades. Fires in the eastern USA almost eliminated red spruce (Picea rubens) from the higher elevations of the Appalachians in the late 19th century [79].

Another example of the contextual vulnerability assessment is the paper by RomeroLankao [80] who concluded in a study of the literature that urban vulnerability is dominated by epidemiological studies and top down assessments, but that inherent urban vulnerability 
and urban resilience approaches (the contextual vulnerability) are what is required in order to illuminate a more complete set of drivers of urban vulnerability.

Other papers that present a contextual framing include Cross et al. [81] who write that their "framework is based on the premise that effective adaptation of management to climate change can rely on local knowledge of an ecosystem and does not necessarily require detailed projections of climate change or its effects". Dawson et al. [82] propose a framework that uses information from different sources to identify vulnerability to species; a methodology they state is also applicable to ecosystems, habitats, ecological communities, and genetic diversity, whether terrestrial, marine, or freshwater. Rykala and Dabrowska [83] discuss a risk assess associated with groundwater in a region with a municipal landfill in which they consider a spectrum of issues including the security system, spatial planning and an assessment of the impact of other variables on groundwater due to terrain and weather conditions.

The cooling or warming of freshwater presents a diverse and conflicting range of risk to fisheries and agricultural food production systems. In the Mekong River basin, hydropower dams have been cooling rivers systematically by a few degrees [84], which is a completely non-greenhouse gas driven phenomenon. On the other hand, shallow lakes such as the Tonle Sap Lake in Cambodia (representing the world's largest inland freshwater fisheries system) have been warming over the last many decades that is attributed to global average warming $[85,86]$. In both cases, the cooling or warming can be driven by the same agricultural water needs of stakeholder farmers.

Dams provide irrigation water for agricultural production while also pushes cooler water downstream through hydropower generation [87]. Deforestation of land on the other hand for use in developing agricultural land raises water temperature in rivers [88]. The risk this human activity presents to the agricultural community is probably minimal in the short-term, yet for the fisheries, such thermal changes can have profound impact on fish biodiversity, fish catch, timing of spawning and the relative abundance of native and invasive species [87]. All this has a consequential impact on livelihood-in Cambodia, $80 \%$ of protein diet comes from fish in Tonle Sap lake, which offers a major source of income to millions [89]. In this particular case, there is clearly an interplay and even a countering effect between the more global phenomenon of warming due to greenhouse gas emissions (Hulme's Framework \#1) and the more local-regional drivers of land cover change and water management, that is not well understood (Hulme's \#2). Yet, a better understanding needs to be achieved which is possible by adopting the bottom-up vulnerability approach and a strong stakeholder engagement campaign [90].

Such stakeholder engagement is currently happening in some sectors-for example in flood and flash flood forecasting in Asian monsoon-dominated river basins [91,92]. The timing and peak level of floods appear to be undergoing a shift due to the combined effects of regional warming, land cover change (deforestation, urbanization) and water management (upstream dam release). The forecasting of such floods are now being successfully visualized in terms of inundation extent at the local scale [92]. This allows stakeholders to know how far the 'water' may spread so that different stakeholders can apply their own definition of risk and its tolerance (such as a farming community interested in delayed sowing or early harvesting and a fisheries community anticipating their fish catch). Such translation of stakeholder input to climate information has been demonstrated to be of more value to the agricultural community while dealing with risks from climate variability and change [93,94].

Generalizing from Kittel's [61] recommendations, the contextual vulnerability approach can be summarized as: (i) monitoring and historical analysis, (ii) apply multiple planning horizons, (iii) expect surprises-scenario planning, (iv) revisit goals and strategies, i.e., adaptive management. and (v) incorporate model predictions into planning to develop scenarios, but only if robust demonstration of their skill has been shown. The Kittel paper writes that in the contextual vulnerability approach, there is a framework for handling uncertainty in an optimal manner while devising strategies to support the adaptive capacity of species and systems. Stemming from these recommendations, planning decisions are 
facilitated by the integration of expert knowledge, scenario planning, a no-regrets goal, and adaptive management.

\section{Discussion}

As documented in this paper, the threats to biodiversity and other aspects of ecosystem function involve much more than the alteration of climate from added $\mathrm{CO}_{2}$ and other GHGs. A focus on just that threat is risking suboptimal and inappropriate mitigation and adaptation responses. In this paper we urge the adoption of the inclusive regional/local focus on risks. With such an approach one can develop the 'best' responses to preserve the health of ecosystem dynamics. This concept even applies with respect to how we assess public health. Lang and Rayner [95] for example, define ecological public health as a framing which integrates the physical aspects (e.g., climate), biological, social, and cultural aspects of public health. They propose such an ecological public health framework as a holistic approach coupling public health science to public health actions.

The large uncertainty that exists for representing human management decisions, including land use and transformation, would likely trump the process scale advances that are being made and represented in the models based on the outcome vulnerability paradigm. Management decisions, such as irrigation, planting dates for agroecosystems or the change in the mobility and green infrastructure within urban ecosystems are often locally undertaken and not adequately documented for models to explicitly consider as part of the downscaling and outcome vulnerability assessment.

The effects of climatic extremes on the ecosystem are also intimately tied in with adaptation measures that are undertaken by the community in anticipation or in tandem with the occurrence of the event. An example is the effect of drought on crop productivity. In a downscaled model, changes in drought forcing through meteorology/hydrology alone would result in lowering of yields. However, more often than not, the agrocommunity alters it practice for planting date, type of variety, and undertakes local measures to try and minimize the loss. These adaptive features also are not currently adequately considered and would need to be a research priority.

\section{Conclusions}

We thus conclude that the contextual bottom-up approach helps bracket the range of uncertainties and risk [32]. It would permit better planning for unexpected threats such as the cold wave disaster in Texas in February 2021 which was a combination of an extreme weather event (cold, ice storms) and failure of planning for such scenarios (energy infrastructure winterization). The disaster due to the desiccation of most of the Aral Sea from the diversion of rivers that naturally flowed into it is an example of more serious and even permanent damage to the environment in that region due to management decisions by the Soviet Union that did not consider all the negative impacts [96]. The bottom-up approach provides a broad methodology involving integration across the spectrum of risks to social and environmental resources. Uncertainties can be folded into this integration. The outcome top-down approach, in contrast, will magnify the effects of uncertainties as the information is progressively downscaled to regions and localities and thus reduce the likelihood of developing effective strategies for dealing with future risks.

A key message of our paper is to emphasize the need to consider coupled feedbacks since the Earth is a dynamically interactive system. This should be done not just in the model structure, but also in its application and subsequent analyses. We recognize that the community is moving toward that goal and we urge an accelerated pace.

Author Contributions: Conceptualization, R.A.P.S., J.A., F.H. and D.N.; methodology, R.A.P.S., J.A., F.H. and D.N.; investigation, R.A.P.S., J.A., F.H. and D.N.; resources, R.A.P.S., J.A., F.H. and D.N.; writing-original draft preparation R.A.P.S.; writing—review and editing, R.A.P.S., J.A., F.H. and D.N.; visualization, R.A.P.S., J.A., F.H., D.N. All authors have read and agreed to the published version of the manuscript. 
Funding: Roger A. Pielke Sr. received funding from the National Science Foundation Award AGS1552487 which supported this work.

Institutional Review Board Statement: Not applicable.

Informed Consent Statement: Not applicable.

Data Availability Statement: Not applicable.

Acknowledgments: We thank the Editors for inviting us to complete this paper. Dallas Staley did her usual outstanding work at finalizing the paper.

Conflicts of Interest: The authors declare no conflict of interest.

\section{References}

1. Sippel, S.; Zscheischler, J.; Reichstein, M. Ecosystem impacts of climate extremes crucially depend on the timing. Proc. Natl. Acad. Sci. USA 2016, 113, 5768-5770. [CrossRef]

2. Felton, A.J.; Smith, M.D. Integrating plant ecological responses to climate extremes from individual to ecosystem levels. Philos. Trans. R. Soc. Lond. B Biol. Sci. 2017, 372, 20160142. [CrossRef]

3. Bauch, M.; Labbe, T.; Engel, A.; Seifert, P. A prequel to the Dantean Anomaly: The precipitation seesaw and droughts of 1302 to 1307 in Europe. Clim. Past 2020, 16, 2343-2358. [CrossRef]

4. Dallmeyer, A.; Claussen, M.; Lorenz, S.; Shanahan, T. The end of the African humid period as seen by transient comprehensive Earth system model simulation of the last 8000 years. Clim. Past 2020, 16, 117-140. [CrossRef]

5. Pielke, R.A., Sr.; Beven, K.; Brasseur, G.; Calvert, J.; Chahine, M.; Dickerson, R.; Entekhabi, D.; Foufoula-Georgiou, E.; Gupta, H.; Gupta, V.; et al. Climate change: The need to consider human forcings besides greenhouse gases. Eos Trans. AGU 2009, 90, 413. [CrossRef]

6. Andrews, T.; Forster, P.M. Energy budget constraints on historical radiative forcing. Nat. Clim. Chang. 2020, 10, 313-316. [CrossRef]

7. Pielke, R.A., Sr. Earth system modelling-An integrated assessment tool for environmental studies. In Present and Future of Modeling Global Environmental Change: Toward Integrated Modeling; Matsuno, T., Kida, H., Eds.; Terra Scientific Publishing, C.O.: Tokyo, Japan, 2001; pp. 311-337.

8. McAlpine, C.A.; Ryan, J.G.; Seabrook, L.; Thomas, S.; Dargusch, P.J.; Syktus, J.I.; Pielke, R.A., Sr.; Etter, A.E.; Fearnside, P.M.; Laurance, W.F. More than CO2: A broader picture for managing climate change and variability to avoid ecosystem collapse. Curr. Opin. Environ. Sustain. 2010, 2, 334-336. [CrossRef]

9. Hulme, M. You've Been Framed: Six New Ways to Understand Climate Change. 2011. Available online: https://theconversation. com/youve-been-framed-six-new-ways-to-understand-climate-change-2119 (accessed on 15 December 2020).

10. Hulme, M. One Earth, many futures, no destination. One Earth 2020, 2. [CrossRef]

11. Polasky, S.; Crépin, A.-S.; Biggs, R.; Carpenter, S.R.; Folke, C.; Peterson, G.; Scheffer, M.; Barrett, S.; Daily, G.; Ehrlich, P.; et al. Corridors of clarity: Four principles to overcome uncertainty paralysis in the Anthropocene. BioScience 2020, 70, 1139-1144. [CrossRef] [PubMed]

12. Parker, D.E. Urban heat island effects on estimates of observed climate change. WIREs Clim. Chang. 2009, 1, 123-133. [CrossRef]

13. Peng, S.; Piao, S.; Ciais, P.; Friedlingstein, P.; Ottle, C.; Bréon, F.M.; Nan, H.; Zhou, L.; Myneni, R.B. Surface urban heat island across 419 global big cities. Environ. Sci. Technol. 2012, 46, 696-703. [CrossRef]

14. Chapman, S.; Watson, J.E.; Salazar, A.; Thatcher, M.; McAlpine, C.A. The impact of urbanization and climate change on urban temperatures: A systematic review. Landsc. Ecol. 2017, 32, 1921-1935. [CrossRef]

15. Pielke, R.A., Sr.; Adegoke, J.O.; Chase, T.N.; Marshall, C.H.; Matsui, T.; Niyogi, D. A new paradigm for assessing the role of agriculture in the climate system and in climate change. Agric. For. Meteor. 2007, 132, 234-254. [CrossRef]

16. Pielke, R.A., Sr.; Pitman, A.; Niyogi, D.; Mahmood, R.; McAlpine, C.; Hossain, F.; Goldewijk, K.K.; Nair, U.; Betts, R.; Fall, S.; et al. Land use/land cover changes and climate: Modeling analysis and observational evidence. WIREs Clim. Chang. 2011, 2, 828-850. [CrossRef]

17. Pielke, R.A., Sr.; Mahmood, R.; McAlpine, C. Land's complex role in climate change. Phys. Today 2016, 69. [CrossRef]

18. Marland, G.; Pielke, R.A., Sr.; Apps, M.; Avissar, R.; Betts, R.A.; Davis, K.J.; Frumhoff, P.C.; Jackson, S.T.; Joyce, L.; Kauppi, P.; et al. The climatic impacts of land surface change and carbon management, and the implications for climate-change mitigation policy. Clim. Policy 2003, 3, 149-157. [CrossRef]

19. Hossain, F.; Arnold, J.; Beighley, E.; Brown, C.; Burian, S.; Dallmeyer, J.; Madadgar, S.; Mitra, A.; Niyogi, D.; Pielke, R.A., Sr.; et al. Local-to-regional landscape drivers of extreme weather and climate: Implications for water infrastructure resilience. J. Hydrol. Eng. 2015, 20. [CrossRef]

20. He, Y.; Lee, E.; Mankin, J.S. Seasonal tropospheric cooling in Northeast China associated with cropland expansion. Environ. Res. Lett. 2019, 15, 034032. [CrossRef]

21. Liu, J.; Niyogi, D. Meta-analysis of urbanization impact on rainfall modification. Sci. Rep. 2019, 9, 1-14. [CrossRef] [PubMed] 
22. Niyogi, D.; Subramanian, S.; Mohanty, U.C.; Kishtawal, C.M.; Ghosh, S.; Nair, U.S.; Ek, M.; Rajeevan, M. The impact of land cover and land use change on the Indian monsoon region hydroclimate. In Land-Atmospheric Research Applications in South and Southeast Asia; Springer: Berlin, Germany, 2018; pp. 553-575. [CrossRef]

23. Chen, C.-J.; Chen, C.-C.; Lo, M.-H.; Juang, J.-Y.; Chang, C.-M. Central Taiwan's hydroclimate in response to land use/cover change. Environ. Res. Lett. 2020, 15, 034015. [CrossRef]

24. Piao, S.; Wang, X.; Park, T.; Chen, C.; Lian, X.; He, Y.; Bjerke, J.W.; Chen, A.; Ciais, P.; Tømmervik, H.; et al. Characteristics, drivers and feedbacks of global greening. Nat. Rev. Earth Environ. 2020, 1, 14-27. [CrossRef]

25. Ullah, A.; Khan, J.; Khan, F.; Shah, L. How vegetation spatially alters the response of precipitation and air temperature? Evidence from Pakistan. Asian J. Atmos. Environ. 2020, 14, 133-145. [CrossRef]

26. Kalnay, E.; Kanamitsu, M.; Kistler, R.; Collins, W.; Deaven, D.; Gandin, L.; Iredell, M.; Saha, S.; White, G.; Woollen, J.; et al. The NCEP/NCAR 40-year reanalysis project. Bull. Am. Meteorol. Soc. 1996, 77, 437-472. [CrossRef]

27. FEMA. The 100 Year Base Flood Standard and the Floodplain Management Executive Order: A Review Prepared for the Office of Management and Budget by the Federal Emergency Management Agency. 1983. Available online: https://apps.dtic.mil/dtic/tr/ fulltext/u2/a141959.pdf (accessed on 10 January 2021).

28. National Research Council. Radiative Forcing of Climate Change: Expanding the Concept and Addressing Uncertainties; Committee on Radiative Forcing Effects on Climate Change, Climate Research Committee, Board on Atmospheric Sciences and Climate, Division on Earth and Life Studies; The National Academies Press: Washington, DC, USA, 2005; p. 222. [CrossRef]

29. Rial, J.A.; Pielke, R.A., Sr.; Beniston, M.; Claussen, M.; Canadell, J.; Cox, P.; Held, H.; de Noblet-Ducoudre, N.; Prinn, R.; Reynolds, J.; et al. Feedbacks and critical thresholds within the Earth's climate system. Clim. Chang. 2004, 65, 11-38. [CrossRef]

30. Sveinsson, O.G.B.; Salas, J.D.; Boes, D.C.; Pielke, R.A., Sr. Modeling of long-term variability of hydroclimatic processes. J. Hydrometeor. 2003, 4, 489-505. [CrossRef]

31. Peters, D.P.C.; Pielke, R.A., Sr.; Bestelmeyer, B.T.; Allen, C.D.; Munson-McGee, S.; Havstad, K.M. Cross-scale interactions, nonlinearities, and forecasting catastrophic events. Proc. Natl. Acad. Sci. USA 2004, 101, 15130-15135. [CrossRef]

32. Pielke, R.A., Sr.; Wilby, R.; Niyogi, D.; Hossain, F.; Dairuku, K.; Adegoke, J.; Kallos, G.; Seastedt, T.; Suding, K. Dealing with Complexity and Extreme Events Using A Bottom-Up, Resource-Based Vulnerability Perspective. In Extreme Events and Natural Hazards: The Complexity Perspective; Sharma, A.S., Bunde, A., Dimri, V.P., Baker, D.N., Eds.; Copyright by the American Geophysical Union, Geophysical Monograph Series; American Geophysical Union: Washington, DC, USA, 2012 ; Volume 196.

33. IPCC. Climate Change 2013: The Physical Science Basis. In Contribution of Working Group I to the Fifth Assessment Report of the Intergovernmental Panel on Climate Change; Stocker, T.F., Qin, D., Plattner, G.-K., Tignor, M., Allen, S.K., Boschung, J., Nauels, A., Xia, Y., Bex, V., Midgley, P.M., Eds.; Cambridge University Press: Cambridge, UK, 2014; p. 1535.

34. McKitrick, R.; Christy, J. Pervasive warm bias in CMIP6 tropospheric layers. Earth Space Sci. 2020, 7. [CrossRef]

35. Wang, Q.; Cheng, L.; Zhang, L.; Liu, P.; Qin, S.; Liu, L.; Jing, Z. Quantifying the impacts of land-cover changes on global evapotranspiration based on the continuous remote sensing observations during 1982-2016. J. Hydrol. 2021. [CrossRef]

36. Burgess, M.G.; Ritchie, J.; Shapland, J.; Pielke, R., Jr. IPCC baseline scenarios over-project CO2 emissions and economic growth. Environ. Res. Lett. 2020. [CrossRef]

37. Pielke, R., Jr. Economic 'normalisation' of disaster losses 1998-2020: A literature review and assessment. Environ. Hazards 2020, 20, 93-111. [CrossRef]

38. Pielke, R., Jr.; Ritchie, J. Distorting the view of our climate future: The misuse and abuse of climate pathways and scenarios. Energy Res. Soc. Sci. 2021, 72, 101890. [CrossRef]

39. Tabor, K.; Williams, J.W. Globally downscaled climate projections for assessing the conservation impacts of climate change. Ecol. Appl. 2010, 20, 554-565. [CrossRef] [PubMed]

40. Winkler, J.A.; Guentchev, G.S.; Liszewska, M.; Tan, P.N. Climate scenario development and applications for local/regional climate change impact assessments: An overview for the non-climate scientist: Part II: Considerations when using climate change scenarios. Geog. Compass 2011, 5, 301-328. [CrossRef]

41. Reeves, M.C.; Moreno, A.L.; Bagne, K.E.; Running, S.W. Estimating climate change effects on net primary production of rangelands in the United States. Clim. Chang. 2014, 126, 429-442. [CrossRef]

42. Platts, P.J.; Omeny, P.; Marchant, R. AFRICLIM: High-resolution climate projections for ecological applications in Africa. Afr. J. Ecol. 2014, 103-108. [CrossRef]

43. Füssel, H.-M. Review and Quantitative Analysis of Indices of Climate Change Exposure, Adaptive Capacity, Sensitivity, and Impacts. Available online: https://documents.worldbank.org/en/publication/documents-reports/documentdetail/885101 468164982209/development-and-climate-change-review-and-quantitative-analysis-of-indices-of-climate-change-exposureadaptive-capacity-sensitivity-and-impacts (accessed on 7 July 2021).

44. O'Brien, K.L.; Eriksen, S.; Nygaard, L.; Schjolden, A. Why different interpretations of vulnerability matter in climate change discourses. Clim. Policy 2007, 7, 73-88. [CrossRef]

45. IPCC. Climate Change. 2014: Synthesis Report. In Contribution of Working Groups I, II and III to the Fifth Assessment Report of the Intergovernmental Panel on Climate Change; Core Writing Team, Pachauri, R.K., Meyer, L.A., Eds.; IPCC: Geneva, Switzerland, 2014; p. 151.

46. Pielke, R.A., Sr.; Wilby, R.L. Regional climate downscaling-What's the point? Eos Forum 2012, 93, 52-53. [CrossRef] 
47. U.S. National Assessment, Fourth National Climate Assessment. Volume II: Impacts, Risks and Adaptation in the United States. 2018. Available online: https:/ / nca2018.globalchange.gov/ (accessed on 1 July 2021).

48. Winkler, J.A.; Arritt, R.W.; Pryor, S.C. Climate Projections for the Midwest: Availability, Interpretation and Synthesis. In U.S. National Climate Assessment Midwest Technical Input Report; Winkler, J., Andresen, J., Hatfield, J., Bidwell, D., Brown, D., Coordinators; The Great Lakes Integrated Sciences and Assessment (GLISA) Center. 2012. Available online: http:/ / glisa.msu. edu/docs/NCA/MTIT_Future.pdf (accessed on 1 July 2021).

49. Byun, K.; Hamlet, A.F. Projected changes in future climate over the Midwest and Great Lakes region using downscaled CMIP5 ensembles. Int. J. Climatol. 2018, 38, e531-e553. [CrossRef]

50. Hamlet, A.F.; Byun, K.; Robeson, S.M.; Widhalm, M.; Baldwin, M. Impacts of climate change on the state of Indiana: Ensemble future projections based on statistical downscaling. Clim. Chang. 2020, 163, 1881-1895. [CrossRef]

51. Kalnay, E. Atmospheric Modeling, Data Assimilation and Predictability; Cambridge University Press: Cambridge, UK, 2003.

52. Pielke, R.A., Sr. Influence of the spatial distribution of vegetation and soils on the prediction of cumulus convective rainfall. Rev. Geophys. 2001, 39, 151-177. [CrossRef]

53. Riehl, H.; Malkus, J.S. On the heat balance in the equatorial trough zone. Geophysica 1958, 6, 504-537.

54. Riehl, H.; Simpson, J.M. The heat balance of the equatorial trough zone, revisited, Contrib. Atmos. Phys. 1979, 52, $287-305$.

55. Nobre, C.; Borma, L.D.S. 'Tipping points' for the Amazon forest. Curr. Opin. Environ. Sustain. 2009, 1, 28-36. [CrossRef]

56. Pielke, R.A., Sr.; Marland, G.; Betts, R.A.; Chase, T.N.; Eastman, J.L.; Niles, J.O.; Niyogi, D.; Running, S.W. The influence of land-use change and landscape dynamics on the climate system: Relevance to climate-change policy beyond the radiative effect of greenhouse gases. Philos. Trans. R. Soc. A 2002, 360, 1705-1719. [CrossRef] [PubMed]

57. NASA Earth Observatory. Deep Freeze and Sea Breeze: Changing Land and Weather in Florida. 2005. Available online: https:/ / earthobservatory.nasa.gov/features / DeepFreeze (accessed on 1 July 2021).

58. Lawler, J.J.; Tear, T.H.; Pyke, C.; Shaw, M.R.; Gonzalez, P.; Kareiva, P.; Hansen, L.; Hannah, L.; Klausmeyer, K.; Aldous, A.; et al. Resource management in a changing and uncertain climate. Front. Ecol. Environ. 2010, 8, 35-43. [CrossRef]

59. Kittel, T.G.F.; Howard, S.; Horn, H.; Kittel, G.M.; Fairbarns, M.; Iachetti, P. A vulnerability-based strategy for incorporating climate change in regional conservation planning: Framework and case study for the British Columbia Central Interior. $B C J$. Ecosyst. Manag. 2011, 12, 7-35.

60. Pielke, R.A., Sr.; de Guenni, L.B. Conclusions. In Vegetation, Water, Humans and the Climate, Global Change-The IGBP Series; Kabat, P., Claussen, M., Whitlock, S., Gash, J.H.C., de Guenni, L.B., Meybeck, M., Pielke, R., Vörösmarty, C.J., Hutjes, R.W.A., Lütkemeier, S., Eds.; Springer: Berlin/Heidelberg, Germany, 2004; pp. 537-538. [CrossRef]

61. Kittel, T.G.F. The vulnerability of biodiversity to rapid climate change. In Vulnerability of Ecosystems to Climate; Seastedt, T.R., Suding, K., Eds.; Elsevier Inc./ Academic Press: Oxford, UK, 2013; Chapter 4.15, Volume 4, pp. 185-201. [CrossRef]

62. Metzger, M.; Rounsevell, M.D.A.; Acosta-Michlik, L.; Leemans, R.; Schröter, D. The vulnerability of ecosystem services to land use change. Agric. Ecosyst. Environ. 2006, 114, 69-85. [CrossRef]

63. Maxim, L.; Spangenberg, J.H.; O'Connor, M. An analysis of risks for biodiversity under the DPSIR framework. Ecol. Econ. 2009, 69, 12-23. [CrossRef]

64. Binder, C.R.; Hinkel, J.; Bots, P.W.; Pahl-Wostl, C. Comparison of frameworks for analyzing social-ecological systems. Ecol. Soc. 2013, 18, 26. [CrossRef]

65. Seastedt, T.R.; Suding, K.N. Preface-Vulnerability of Ecosystems to Climate. Clim. Vulnerability 2013. [CrossRef]

66. Kling, M.M.; Auer, M.; Comer, S.L.; Ackerly, P.J.; Hamilton, D.D. Multiple axes of ecological vulnerability to climate change. Glob. Chang. Biol. 2020, 26, 2798-2813. [CrossRef] [PubMed]

67. Ordonez, A. Points of view matter when assessing biodiversity vulnerability to environmental changes. Glob. Chang. Biol. 2020, 26, 2734-2736. [CrossRef] [PubMed]

68. Pielke, R.A., Jr. The Honest Broker: Making Sense of Science in Policy and Politics; Cambridge University Press: Cambridge, UK, 2007. [CrossRef]

69. Moss, R.; Edmonds, J.; Hibbard, K.; Manning, M.R.; Rose, S.K.; van Vuuren, D.P.; Carter, T.T.; Emori, S.; Kainuma, M.; Kram, T.; et al. The next generation of scenarios for climate change research and assessment. Nature 2010, 463, 747-756. [CrossRef] [PubMed]

70. Kabat, P.; Claussen, M.; Whitlock, S.; Gash, J.H.C.; de Guenni, L.B.; Meybeck, M.; Pielke, R.; Vörösmarty, C.J.; Hutjes, R.W.A.; Lütkemeier, S. (Eds.) Vegetation, Water, Humans and the Climate: A New Perspective on an Interactive System; Global Change-The IGBP Series; Springer: Berlin, Germany, 2004; p. 566.

71. Lovelock, J.; Margulis, L. Atmospheric homeostasis by and for the biosphere: The Gaia hypothesis. Tellus 1974, 26, 2-10. [CrossRef]

72. Vörösmarty, C.; (The Graduate Center of the City University of New York, New York, NY, USA). Personal Communication, 2000.

73. Vörösmarty, C.; Green, P.; Salisbury, J.; Lammers, R. Global water resources: Vulnerability from climate change and population growth. Science 2000, 289, 284-288. [CrossRef] [PubMed]

74. Hobbs, G. The Role of Climate in Shaping Western Water Institutions. Water, Climate, and Uncertainty: Implications for Western Water Law, Policy, and Management, Natural Resources Law Center, University of Colorado, Boulder, CO, Summer Conference, 11-13 June 2003. p. 61. Available online: https:/ / scholar.law.colorado.edu/water-climate-uncertainty/ 5 (accessed on 1 July 2021). 
75. Stohlgren, T.J.; Jarnevich, C.S. Risk assessment of invasive species. In Invasive Species Management: A Handbook of Principles and Techniques; Clout, M.N., Williams, P.A., Eds.; Oxford University Press: New York, NY, USA, 2009; pp. $19-35$.

76. Stohlgren, T.; Pyšek, P.; Kartesz, J.; Nishino, M.; Pauchard, A.; Winter, M.; Pino, J.; Richardson, D.; Wilson, J.; Murray, B.R.; et al. Globalization Effects on Common Plant Species. In Encyclopedia of Biodiversity, 2nd ed.; Levin, S.A., Ed.; Academic Press: Waltham, MA, USA, 2013; Volume 3, pp. 700-706. [CrossRef]

77. Barnett, D.T.; Jarnevich, C.; Chong, G.W.; Stohlgren, T.J.; Kumar, S.; Holcombe, T. Ecology and Space: A Case Study in Mapping Harmful Invasive Species. In Mapping Across Academia; Brunn, S., Dodge, M., Eds.; Springer: Dordrecht, The Netherlands, 2017; pp. 63-81. [CrossRef]

78. Wiens, J.J. Climate-related local extinctions are already widespread among plant and animal species. PLoS Biol. 2016, 14, e2001104. [CrossRef]

79. Pielke, R.A., Sr. The distribution of spruce in west-central Virginia before lumbering. Castanea 1981, 46, $201-216$.

80. Romero-Lankao, P.; Qin, H.; Dickinson, K. Urban vulnerability to temperature-related hazards: A meta-analysis and metaknowledge approach. Glob. Environ. Chang. 2012, 22, 670-683. [CrossRef]

81. Cross, M.S.; Zavaleta, E.S.; Bachelet, D.; Brooks, M.; Enquist, C.; Fleishman, E.; Graumlich, L.; Groves, C.; Hannah, L.; Hansen, L.; et al. The Adaptation for Conservation Targets (ACT) framework: A tool for incorporating climate change into natural resource management. Environ. Manag. 2012, 50, 341-351. [CrossRef] [PubMed]

82. Dawson, T.P.; Jackson, S.; House, J.I.; Prentice, I.C.; Mace, G.M. Beyond predictions: Biodiversity conservation in a changing climate. Science 2011, 332, 53-58. [CrossRef]

83. Rykała, W.; Dabrowska, D. Risk assessment for groundwater in the region of municipal landfill systems in Tychy-Urbanowice (Southern Poland). Environ. Socio-Econ. Stud. 2020, 8, 9-17. [CrossRef]

84. Bonnema, M.; Hossain, F.; Nijssen, B.; Holt, J. Hydropower's hidden transformation of rivers in the Mekong. Environ. Res. Lett. 2020, 15, 044017. [CrossRef]

85. Arias, M.E.; Cochrane, T.A.; Piman, T.; Kummu, M.; Caruso, B.S.; Killeen, T.J. Quantifying changes in flooding and habitats in the Tonle Sap Lake (Cambodia) caused by water infrastructure development and climate change in the Mekong Basin. J. Environ. Manag. 2012, 112, 53-66. [CrossRef]

86. Daly, K.; Ahmad, S.K.; Bonnema, M.; Beveridge, C.; Hossain, F.; Nijssen, B.; Holtgrieve, G. Recent warming of the Tonle Sap Lake, Cambodia: Implications for one of the world's most productive inland fisheries. Lakes Reserv. 2020, 25, 133-142. [CrossRef]

87. Sabo, J.L.; Ruhi, A.; Holtgrieve, G.W.; Elliott, V.; Arias, M.E.; Ngor, P.B.; Räsänen, T.A.; Nam, S. Designing river flows to improve food security futures in the Lower Mekong Basin. Science 2017, 358, eaao1053. [CrossRef]

88. Brown, G.W.; Krygier, J.T. Effects of clear-cutting on stream temperature. Water Resour. Res. 1970, 6, 1133-1139. [CrossRef]

89. Cochrane, T.S.; Arias, M.E.; Piman, T. Historical impact of water infrastructure on water levels of the Mekong River and the Tonle Sap System. Hydrol. Earth Syst. Sci. 2014, 18, 4529-4541. [CrossRef]

90. Hossain, F.; Shum, C.K.; Turk, F.J.; Biancamaria, S.; Lee, H.; Limaye, A.; Hossain, M.; Shah-Newaz, S.; Mazumder, L.C.; Ahmed, T.; et al. Crossing the "Valley of Death": Lessons learned from implementing an operational satellite-based flood forecasting system. Bull. Am. Meteor. Soc. 2014, 95, 1201-1207. [CrossRef]

91. Sikder, S.; Hossain, F. Improving operational flood forecasting in monsoon climates with bias-corrected quantitative forecasting of precipitation. Int. J. River Basin Manag. 2018, 17, 411-421. [CrossRef]

92. Biswas, N.K.; Hossain, F.; Bonnema, M.; Haque, A.; Biswas, R.; Bhuyan, A.; Hossain, A. A computationally efficient flashflood early warning system for a mountainous and transboundary river basin in Bangladesh. J. Hydroinform. 2020, 22, 1672-1692. [CrossRef]

93. Niyogi, D.; Andresen, J. Useful to Usable (U2U): Transforming Climate Variability and Change Information for Cereal Crop Producers. In AGU Fall Meeting Abstracts; American Geophysical Union: San Francisco, CA, USA, 2011; p. GC13A-0960.

94. Prokopy, L.S.; Carlton, J.S.; Haigh, T.; Lemos, M.C.; Mase, A.S.; Widhalm, M. Useful to usable: Developing usable climate science for agriculture. Clim. Risk Manag. 2017, 15, 1-7. [CrossRef]

95. Lang, T.; Rayner, G. Ecological public health: The 21st Century's big idea? An essay by Tim Lang and Geof Rayner. BMJ 2012, 345, e5466. [CrossRef] [PubMed]

96. Michlin, P. The Aral Sea disaster. Ann. Rev. Earth Planet. Sci. 2007, 35, 47-72. [CrossRef] 